\title{
射出成形品の板厚方向の層構造と成形過程に おける樹脂挙動に関する一考察
}

\author{
石島 守*1 - 山部昌*1 - 永田真一*2 \\ 新 保 實*2 ・宮 野 靖*2
}

\section{The Relation between the Layered Structure and the Resin Behavior in Injection Molding Process}

\author{
Mamoru Ishijima*1, Masashi Yamabe*1, Shinichi Nagata*2 \\ Minoru Shimbo*2, Yasushi Miyano*2
}

\begin{abstract}
In injection molding process, the molten resin flows speedy into the thin cavity and this causes high shear stress condition. In addition, the resin is rapidly cooled and solidified from the surface of the molded even if the molten resin flows in the cavity. It was reported that these phenomena result in the layered structure of the molded.

In this paper, the cross-sectional polarizing microphotograph of injection molded plates were analyzed for various molding condition so as to examine the effect of molding condition on the layered structure. In order to clarify the generating mechanism of layered structure, the observed layered structures were correlated with the solidified layer thickening process during injection molding and time dependence of maximum shear stress, which were obtained by the injection molding simulation. As a result, it was shown that the maximum shear stress occurred between the solid and liquid layers drastically changes when the thickening rate of the solidified layer changes discontinuously, and that the depth of the boundaries among the layers is in accordance with the depth at where the maximum shear stress changes drastically. These two facts enable us to conclude that the generation of the layered structure is dominated both by the changes of solidified layer thickening and by the maximum shear stress between the solid and liquid layers.
\end{abstract}

Key words : Injection molding simulation/Layered structure/Solidified layer/Maximum shear stress/Generation Mechanism

$E$ *1 日産自動車(株) 技術開発センター

厚木市岡津古久 560-2（广 243-01）

Simultaneous Engineering Center

Nissan Motor Co., Ltd.

560-2 Okatsukoku, Atsugi, Kanagawa 243-01 Japan

*2 金沢工業大学 材料システム工学科

石川県石川郡野々市町扇が丘 7-1 (广 921)

Department of Mechanical System Engineering

Kanazawa Institute of Technology

7-1 Ohgigaoka, Nonoichi, Ishikawa-gun, Ishikawa

921 Japan

1995. 6. 3 受理

\section{1. 緒言}

射出成形では高温の樹脂が高速でキャビティ内に流 入し，な掞かつ流入過程に拈いても金型からの急冷や 樹脂のせん断発熱などが生じる．すなわち，金型内の 樹脂はキャビティ内で厚み方向に不均一な高せん断応 力や複雑な温度履歴を受けている.このよらな現象に より，射出成形品の板厚方向には層構造が見られると 報告されている1) 7).

著者らは成形品の断面偏光写真から板厚方向を中央 
Table 1 Molding condition of specimens

\begin{tabular}{|c|c|c|c|c|c|}
\hline $\begin{array}{l}\text { Case } \\
\text { No. }\end{array}$ & Molding condition & $\begin{array}{l}\text { Fill time } \\
\text { (s) }\end{array}$ & $\begin{array}{l}\text { Holding } \\
\text { pressure } \\
(\mathrm{MPa})\end{array}$ & $\begin{array}{l}\text { Holding } \\
\text { time } \\
\text { ( } \mathrm{s})\end{array}$ & $\begin{array}{l}\text { Cooling } \\
\text { time } \\
(\mathrm{s})\end{array}$ \\
\hline Case 1 & High speed injection & 4.3 & 25 & \multirow{4}{*}{10} & \multirow{4}{*}{30} \\
\hline Case 2 & Low pressure holding & \multirow{3}{*}{ 8. 3} & 15 & & \\
\hline Case 3 & Standard condition & & 25 & & \\
\hline Case 4 & High pressure holding & & 40 & & \\
\hline
\end{tabular}

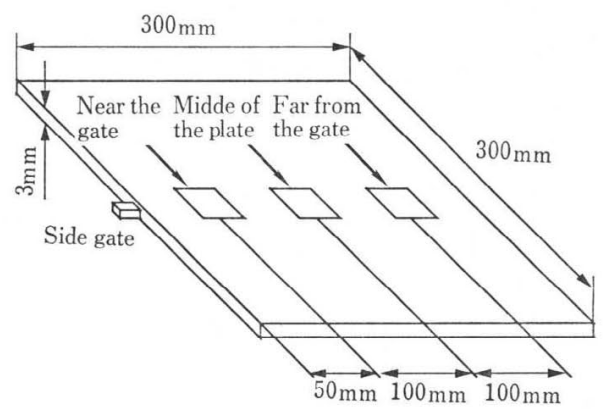

Fig. 1 Geometry of the molded plate and the location of specimens

層, 中間層, 表面層の 3 層に大別し, 各層の物性值に 分布があることを明らかにしてきた. なた，これらの 物性值分布を考虑し, 熱粘弾性モデルを用いることに より射出成形品の板厚方向の残留応力分布が定量的に 計算できることを示してきだ．

この板厚方向の物性值分布に起因する残留応力は射 出成形品に発生するそり不良の一要因であると考党ら れる. したがって, 射出成形品のそり量を定量的に予 測するためには, 製品の面内の収縮量差や板厚方向の 温度分布履歴の他に, 成形品の層構造の生成メカニズ ムを明らかにし, 各層での物性值分布をその生成メカ ニズムから予測し, 物性值分布に起因する残留応力を
も考慮する必要がある，そこで, 成形中の測定が困難 な樹脂状態を射出成形流動解析により把握し, その結 果から層構造や物性值分布を予測し，これをそり变形 解析に織り込んで計算しなければならない.

本稿ではまず，様々な条件で成形した射出成形品の 各部位での断面層構造を偏光顕微鏡を用いて分析し, 層構造の成形条件, 位置依存性を調べるとともに層構 造の生成原因の推察を行ら，そして，射出成形シミュ レーションを用いて成形過程での樹脂挙動の経時変化 を追うことにより，層構造の発生メカニズムについて 考察し, 樹脂流動解析による層構造子測の可能性を検 討する.

\section{2. 成形品断面内の層構造の分析}

\section{1 成形材料および試料の成形条件}

本研究で用いた樹脂は，エラストマー，カーボンブ ラックタルクが各々 $27 \mathrm{wt} \%, 2 \mathrm{wt} \%, 10 \mathrm{wt} \%$ の 割合で配合された耐衝撃性グレードのポリプロピレン (PP) である. 成形品は一辺の中央に断面寸法 $1.5 \times 3$ $\mathrm{mm}$ のサイドゲートを有する寸法 $300 \times 300 \times 3 \mathrm{~mm}$ の平板であり, Table 1 の 4 条件で, 型締力 415 ト ン (4.07 MN) 射出成形機を用いて成形した. 試料は Fig. 1 に示示 3 個所から切り出し, 流れ方向に垂直な 断面を分析する. 切り出された試料は寸法 $3.0 \times 5.0$

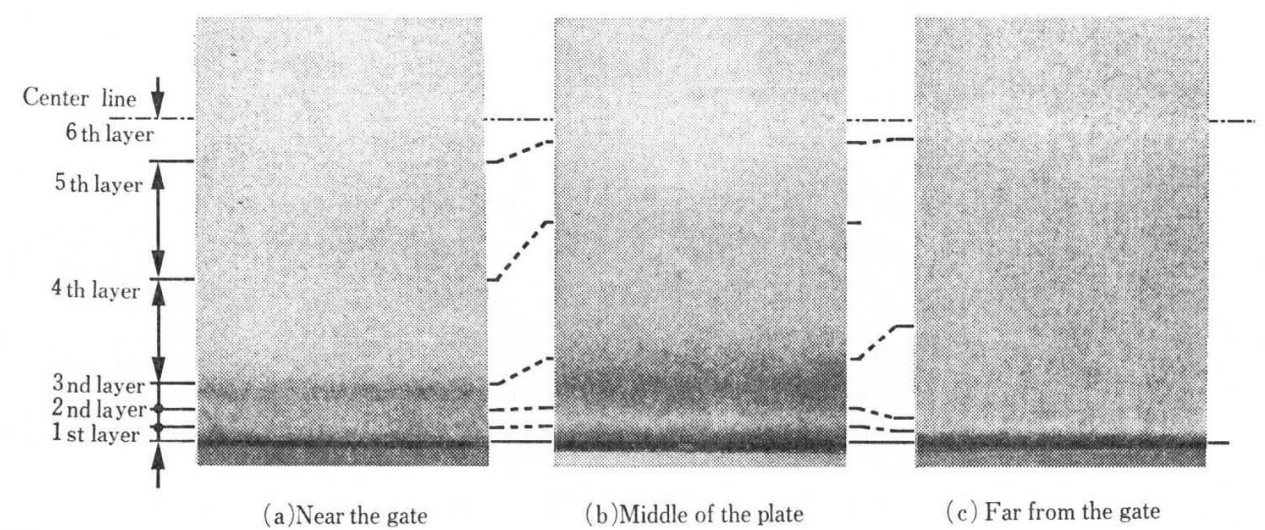

Fig. 2 Cross-sectional polarizing microphotograph of injection molded plate under the high speed injection condition 


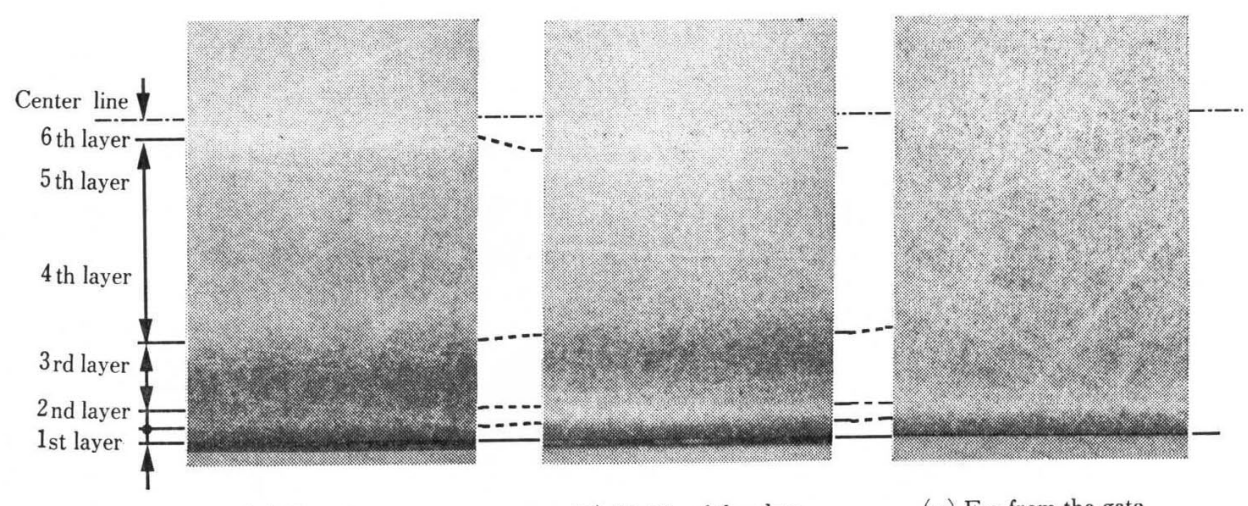

$500 \mu \mathrm{m}$
(a) Near the gate
(b) Middle of the plate
(c) Far from the gate

Fig. 3 Cross-sectional polarizing microphotograph of injection molded plate under the low pressure condition

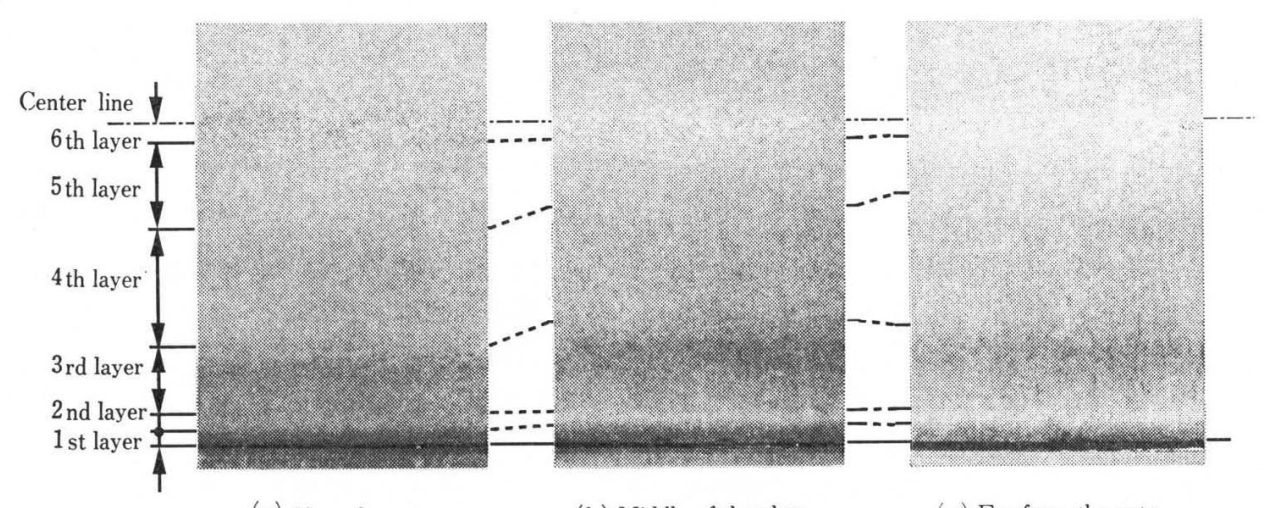
(a) Near the gate
(b) Middle of the plate
(c) Far from the gate

Fig. 4 Cross-sectional polarizing microphotograph of injection molded plate under the standard condition

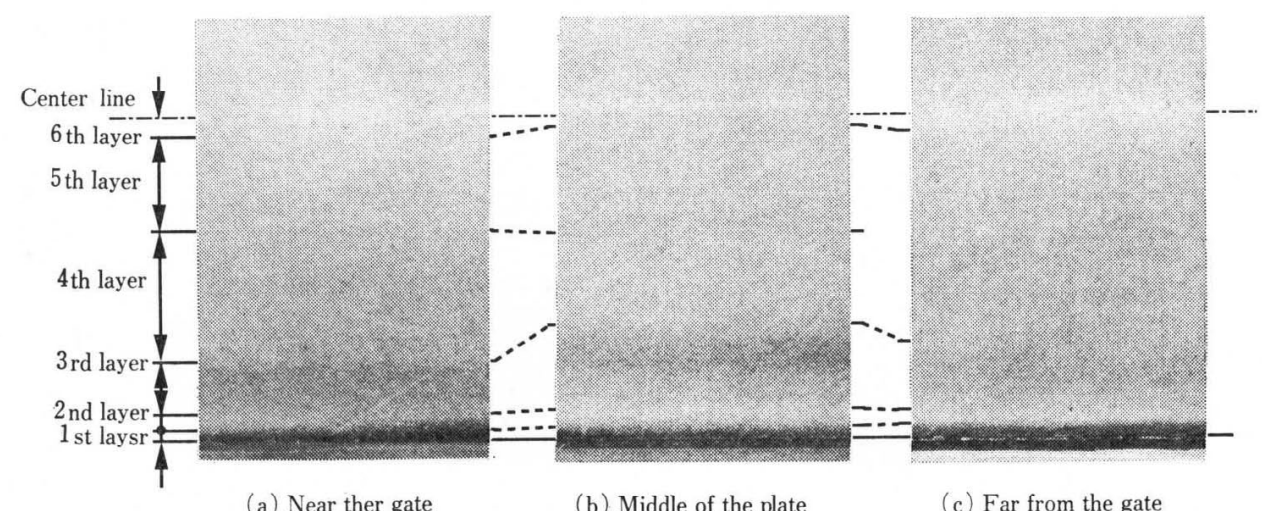

Fig. 5 Cross-sectional polarizing microphotograph of injection molded plate under the high pressure condition 
$\times 5.0 \mathrm{~mm}$ 程度に加工し, エポキシ樹脂で固めて $1 \mu \mathrm{m}$ ダイヤモンドにより最終研摩を行う。 そして, 金属䫒 微鏡 (ニコン製 TME-NR) を用い, 倍率 50 倍で反 射偏光観察法にて偏光写真を撮影した.

\section{2 結 果}

各成形条件で成形した試料の偏光顕微鏡断面写真を Figs. 2 5 亿示す. 本材料のよらなブレンド材に沶い ては樹脂流動により板厚方向に構成物質の分布が生じ るため，PP 単体の成形品のように結晶化度，結晶形 態だけで層の構造分析を行らことは難しい，また，本 材料にはカーボンブラックが含有されているために結 晶の状態を把握することはさらに困難である，とこで 偏光顕微鏡写真から読久取れる各層の境界面の識別を 行った.

層構造の分析のため，Fig. 4（a） に示す標準成形 条件ゲート部での層構造を例にとって詳しく観察する。 断面偏光写真により, 表面側から順に各 $60 \mu \mathrm{m}$ の黒 色層之白色層, $300 \mu \mathrm{m}$ の黒色層が存在し, さらに中 心側に $700 \mu \mathrm{m}$ 程度の灰色の層, $300 \mu \mathrm{m}$ の灰色層と 続き，中心部には $60 \mu \mathrm{m}$ の白色層が存在している。 これらの層の構成比率は成形条件，および成形品の部 位により差異が見られる，これらの層を便宜上，表面 側から第 $1 \sim 6$ 層之称する.

撮影結果より第 $1 ， 2$ ，抢よび 6 層では部位，成形 条件の差異による境界面の位置変化は小さく，また第 4, 5 層では境界面が明確でないために, 部位, 成形 条件の違いによる差異の判別は困難である.これに対 乙, 第 3 層は比較的境界面が明確であり, 部位, 成形 条件の依存性も見られる．この層は全ての成形条件に おいて, ゲート近傍部より中央部の方が境界面の位置 は表面から深く，また端部では他部と比較して第 3 層 の境界が不明瞭になっている、いっぽう, 成形条件に よる差異としては射出速度の速い成形品の第 3 層の境 界面は他の条件の成形品よりも表面に近い傾向にある。

\section{3 層構造生成メカニズムの考察}

一般に PPのような結唱性樹脂を材料とした射出成 形品断面の偏光顕徽鏡写真に打ける層構造は，板厚方 向の結晶化度や結晶形態の差異, 拈よび分子配向の違 いにより現れる．これら結晶状態や分子配向は樹脂の 冷却速度と固化時のせん断状態に大きく依存しており 冷却速度の増大につれて結晶化度は低くなり，またせ ん断応力が大きくなると分子の流動方向の配向度が大 きくなる.

以上から，偏光顕微鏡により区分される層間の境界 面は結晶化度や分子配向が急激に変化する部位，すな わち, 樹脂の冷却速度や最大せん断応力の急変する部 位に生成されると考えられる。

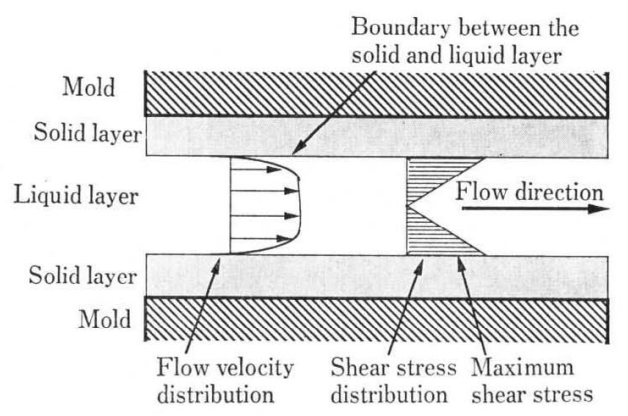

Fig. 6 Schematic diagram showing the flow velocity and shear stress distribution through the thickness

いっぽら，射出成形に扮いて，成形過程は射出，保 圧，拉よび冷却過程に分類でき，去れぞれの過程で樹 脂の流量は大きく変化し，これに伴って発生するせん 断応力も変化する．これらのことから，層間の境界面 はせん断速度の急変する射出から保圧への切り替兄時 保圧力の切り替壳時やゲートシールの発生時に関係が あると推察できる。

このような観点から，第 3 層が射出過程に生成され ると仮定し, 第 3 層の境界面の位置依存性の原因を推 察する。

射出された溶融樹脂はサイドゲートから金型内へ流 入するため，ゲート近傍では拡大流となり，ゲートか ら離れるにつれて平行流になる。 このため, ダート近 傍では樹脂の流動断面積が小さく，流速が大さくなる。 よって，流動によるせん断発熱が大きくなり，流動過 程での固化層は薄くなくなり，境界面は表面近くに生 成される、ゲートから遠ざかると流動断面積が大きく なるため流速が小さくなる，そして，せん断発熱量が 減少するため流動中の固化層は厚くなり, 境界面は表 面から離れた位置に生成される，射出条件による差異 も同様に考兄られる.すなわち，射出時間の短縮によ る流量の増大がせん断発熱量を大きくし，また，流動 中の放熱量が少なくなるため，流動時の固化層の厚み を小さくし，その結果，境界層の生成位置が浅くなる と考觉られる.これらの推察は偏光顕微鏡写真から得 られた第 3 層の境界面の位置变化と一致している.

以上のことから，第 3 層は射出過程に生成する層々 考完ることができる.

\section{3. 解析による層構造生成機構の解明}

射出成形シミュレーションを用いて, 実測の困難な 金型内の樹脂挙動と実測された層構造の関係を調べ， 層構造の生成メカニズムを明確にする.

一般に，射出成形に批いてキャビティ内を樹脂が流 動する場合，ある一部位汇着目すれぱ，Fig. 6 亿示す 
ように樹脂は金型からの冷却により，型に接する表面 から固化が進展し，時間とともに固化層が厚くなり， また，流動によるせん断応力は速度勾配の最も大きな 固化層と流動層の境界面で最大值を示す.

ここでは，固化層成長の経時変化と固化層と流動層 の境界面に発生する最大せん断応力の経時変化を樹脂 挙動として着目している.

\section{1 解 析条件}

解析には射出成形統合シミュレーションソフトウェ $\boldsymbol{\gamma}$ (SDRC 製 I-DEAS Master Series Thermoplastics)
を用いて，樹脂流動解析のみを行った．本ソフトウエ アでは樹脂流動を Hele-Shaw 流として扱い, 温度分 布は板厚方向に 24 点の積分点をもたせた三次元で計 算している.また，流動により発生するせん断発熱, 樹脂の金型からの冷却により発生，成長する固化層を も考慮している．ただし，結晶化現象の取り扱いは樹 脂材料データと括ける比熱, 熱伝導率, 比容積の温度 依存性のみで考虑しているため，冷却速度，および压 力による結晶化温度の变動は表せない，解析条件は Table 1 と同等とし, 金型温度, 樹脂温度は実測值 (各

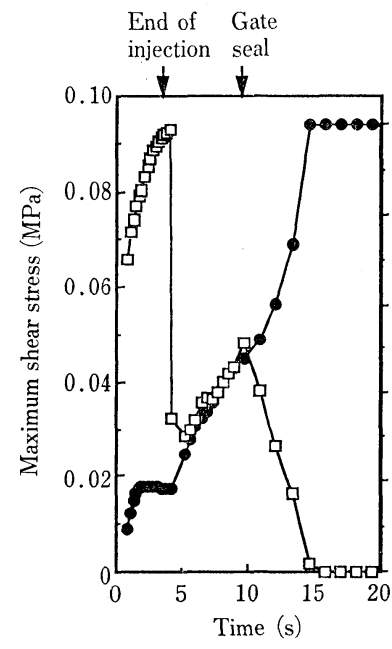

(a)Near the gate

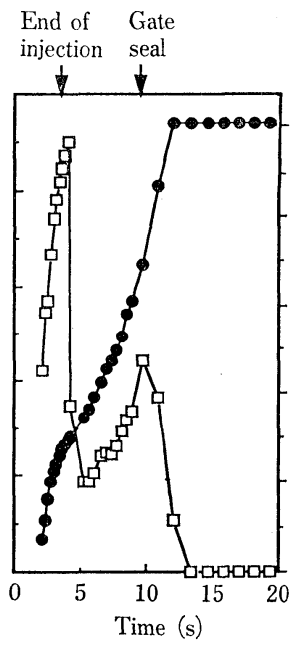

(b) Middle of the plate

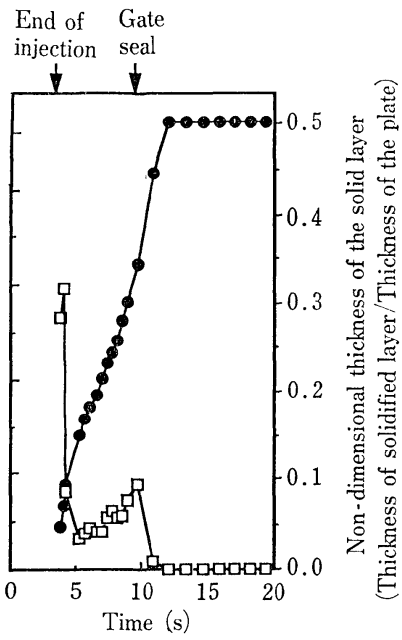

(c) Far from the gate

Fig. 7 Time dependence of the solid layer thickness and maximum shear stress under the high speed injection condition $($ : Thickness, $\bigcirc$ : Shear stress)

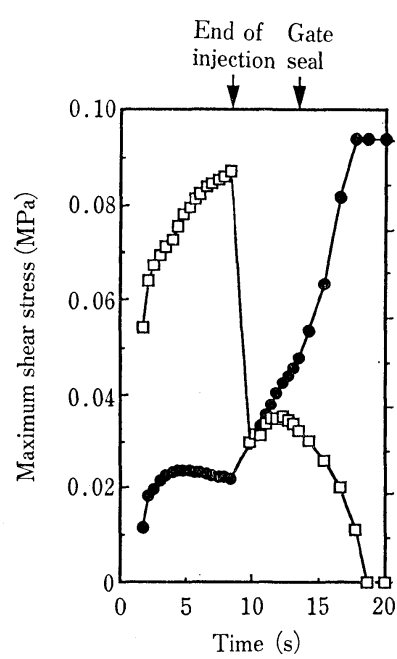

(a) Near the gate

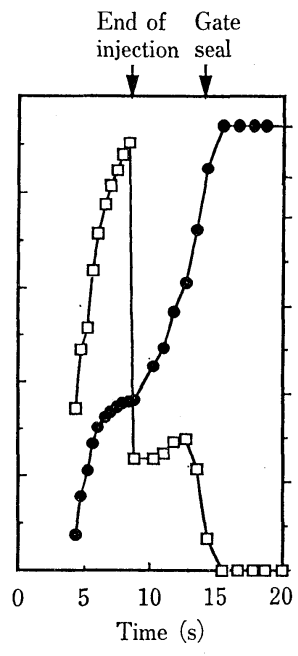

(b) Middle of the plate

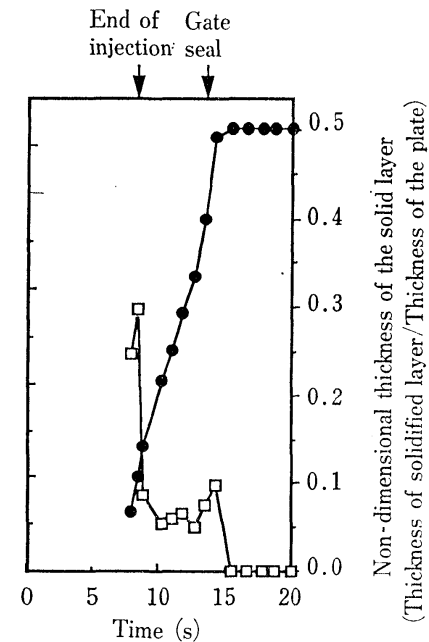

(c) Far from the gate

Fig. 8 Time dependence of the solid layer thickness and maximum shear stress under the low pressure condition : Thickness, $\bigcirc$ : Shear stress) 
各 $\left.40^{\circ} \mathrm{C}, 220^{\circ} \mathrm{C}\right)$ を用いた。

解析に使用する材料データは, 比熱, 熱伝導率, 粘 度, 密度扣よび流動停止温度である. 比熱の測定は DSC 測定装置を用いて冷却速度 $10^{\circ} \mathrm{C} / \mathrm{min}$ の条件で 行った. 流動停止温度は, この降温下での DSC 測定 結果に打けるピークを示す温度, すなわち結晶化温度 を用いた．密度は圧力，温度依存性の測定が可能な $P V T$ 測定機で得られたデータを用いるが，この測定 は定常状態で行われるため, 冷却条件下で得られた遷 移温度を用いて修正した。 また, 熱伝導率は Cornell
大学の K-systerm II により得られた温度依存のデー タを用いた。

\section{2 解析結果および考察}

Figs. 7〜10 は断面偏光写真を撮った位置での板厚 に対する固化層の占有率と固液境界面で発生する最大 せん断応力の時問依存性を示したるのである.なお， 固液境界面は板厚方向の温度が流動停止温度になった 位置として定義される.

a. せん断応力の時間依存性

せん断応力の経時変化は成形条件, 部位によらず同

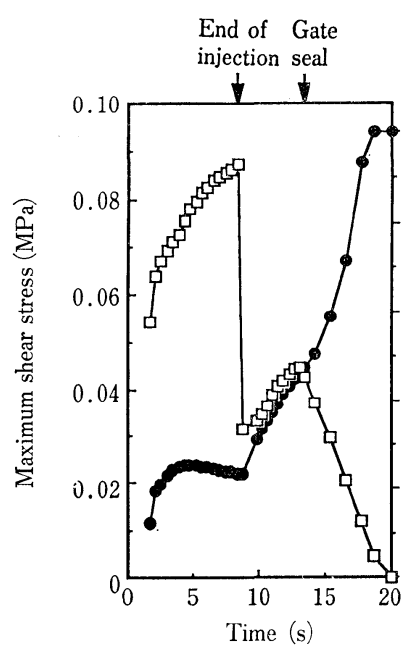

(a) Near the gate

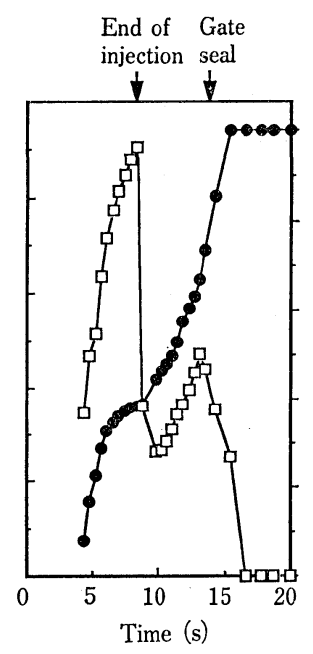

(b) Middle of the plate

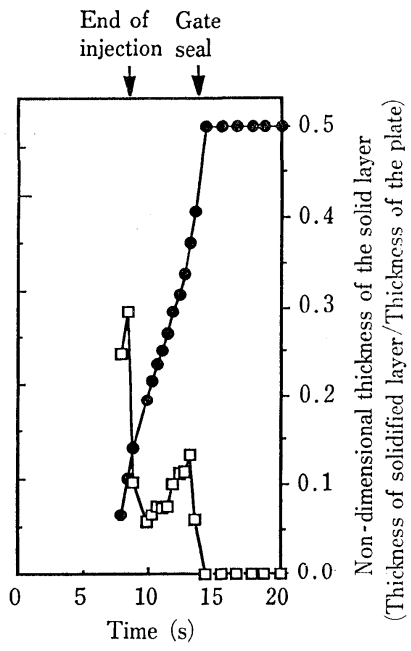

(c) Far from the gate

Fig. 9 Time dependence of the solid layer thickness and maximum shear stress under the standard condition (Thickness, $\bigcirc:$ Shear stress)

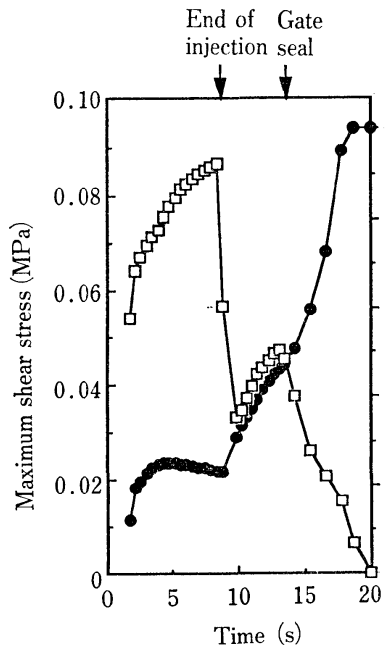

(a) Near the gate

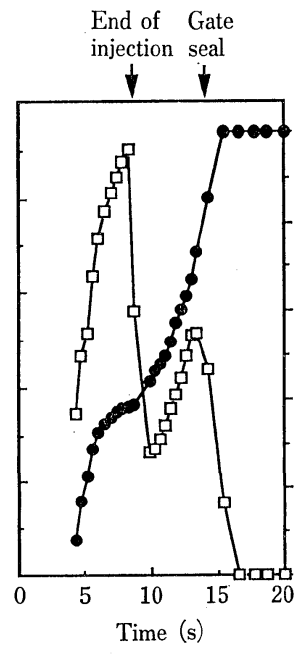

(b) Middle of the plate

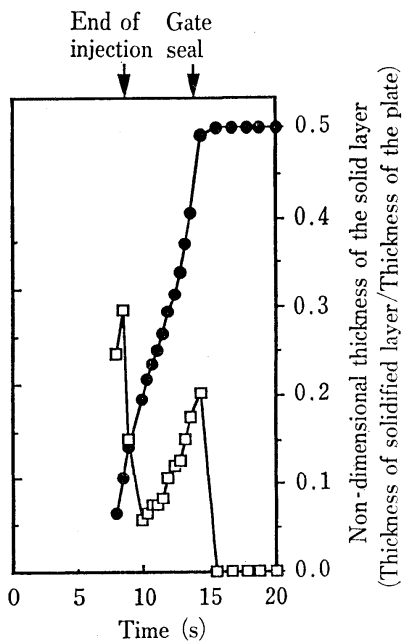

(c) Far from the gate

Fig. 10 Time dependence of the solid layer thickness and maximum shear stress under the high pressure condition ( : Thickness, $\bigcirc$ : Shear stress) 


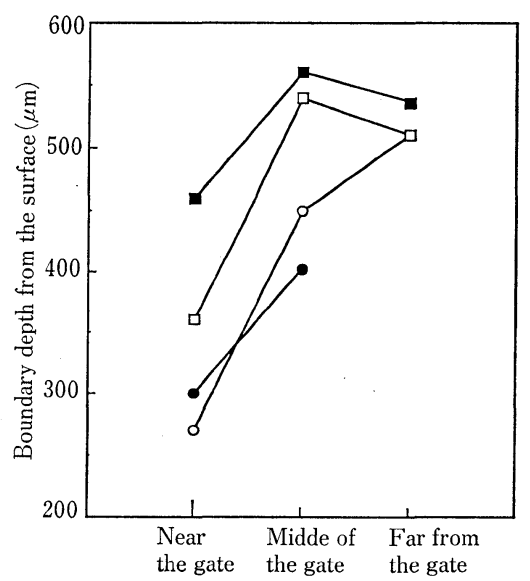

$\bigcirc$ : Depth of maximum shear stress at the end of injection (High speed condition), $\square$ : Depth of maximum shear stress at the end of injection (Standard condition), : Depth of boundary between \#3 and \#4 layers (High speed condition), : Depth of boundary between $\# 3$ and $\# 4$ layers (Standard condition)

Fig. 11 Boundary depth from the surface (Caused at the end of injection)

一傾向を示して扣り，射出終了時とダートシール時間 にピークをもっている（ゲートシール時間は高速条件 では $9.8 \mathrm{~s}$ ，その他は $13.6 \mathrm{~s}$ である).

\section{b . 固化層の成長}

固化層の時間依存性に着目すると, 成形条件に関わ らず，各部位で共通の傾向が見られる. そこで Fig. 9 に示す標準条件の結果について詳細を述べる.

(1) ゲート近傍

ゲート付近では，射出開始とともに固化層は急成長 するが，その後，射出終了までは樹脂のせん断発熱に より固化層の成長が停留あるいは減少し, 保王過程の 開始から固化層が再度成長するため，不連続になって いる．保圧開始後は，葟ぼ一定の増分で固化層が生成 し, ゲートシール時間で再び不連続点が現れ, 固化層 の単位時間当たりの増加量で表される固化層成長速度 （固化層の時間依存性を示すグラフの傾き）は大きく なっている．また，この時間はせん断応力のピーク発 生時間とほぼ一致している.すすねわ，保圧に伴う微 小流動による高温の溶融樹脂の供給やせん断発熱が固 化層の成長を遅らせていることがわかる.

\section{(2) 中央部}

中央部でもゲート近傍と同様に，2つの不連続点が 同一のタイミング, すなわち射出完了時とゲートシー ル時に現れているが，その時の固化層厚さはゲート近 傍部と比較して大きくなっている. これはゲート近傍 部より流動断面積が大きいため，樹脂流速が小さくな

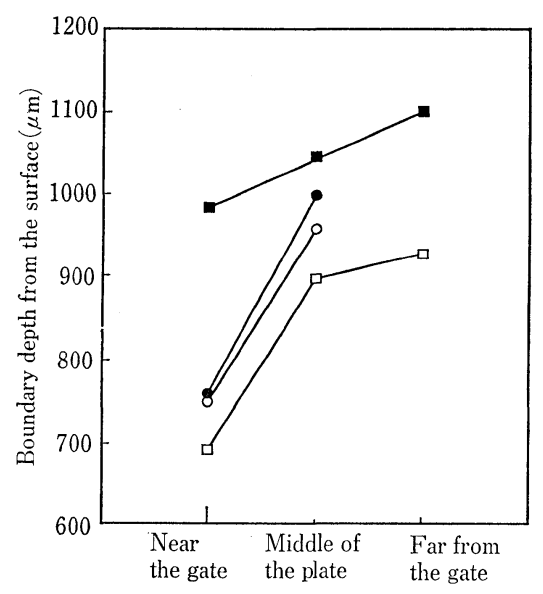

$\bigcirc:$ Depth of maximum shear stress at the end of injection (High speed condition), $\square$ : Depth of maximum shear stress at the end of injection (Standard condition), : Depth of boundary between $\# 4$ and $\# 5$ layers (High speed condition), Depth of boundary between \#4 and \#5 layers (Standard condition)

Fig. 12 Boundary depth from the surface (Caused by gate seal)

り，それによるせん断発熱量が減少するからと考兄ら れる.

この現象はせん断応力の変化からも説明できる．射 出開始直後は流動断面積がゲート近傍部より大きいた め，せん断応力は低いが，固化層成長速度がゲート近 傍部より大きいために時間の経過とともに流動断面積 が減少し，せん断応力が高くなっている.

\section{(3) 端末近傍}

流速が遅くなるため，せん断発熱による固化層の成 長の停留はみられない，固化層成長速度は射出時より も保圧時の方が低く, ゲートシール後, 再度高くなる.

c . 成形条件の差異によるせん断応力履歴の変化

(1) 射出速度による変化

射出速度の上昇に伴い, 射出過程でのせん断応力は 大きくなり，また，保圧過程に怙いても同様の現象が 見られる. 保圧過程におけるせん断応力值の増大は射 出速度の高速化により樹脂温が高くなり，射出終了か らゲートシールまでの保圧力が作用する時間が長くな るためと考兄られる. 固化層の成長の差異は固化層の 成長停留時の厚みが薄くなっていることが特徵的であ る.

(2) 保圧条件による変化

保圧条件の変化は保圧過程でのせん断応力に大きく 影響しているが，他への影響は小さい，低保圧条件で は保圧による補償流動が少ないため, 保圧時のせん断 応力の増大は生じていないと考えられる.これはゲー 
トシール以前にゲート近傍のせん断応力が減少してい ることからも推測できる.

\section{3 層構造生成メカニズム}

前節では固化層の成長とせん断応力の变化をせん断 発熱，流速変化などのキャビティ内の樹脂挙動により 定性的に説明することができた．また，固化層成長と 最大せん断応力值の変動の間には密接な関係があるこ とが確認できた。これらの現象と実際の層構造の関係 を調べるため, 射出成形シミュレーション結果から得 られた固化層成長速度の急変層と偏光顕微鏡写真から 識別した層の厚及を比較した。

Fig. 11 に第 3 層と第 4 層の境界面の深さと射出と 保圧の切り替えによるせん断応力急変層深さの関係を, Fig. 12 飞第 4 層と第 5 層の境界面の深さとゲートシ ールによるせん断応力急変層深さの関係を示す。な和， 断面偏光写真飞招いて境界面が不明確なるのについて は表示していない。

解析により求めた境界面と断面偏光写真による第 3 層之第 4 層間の境界面深さ比較では, 各々の界面深さ は定量的には最大 $20 \%$ 程度の誴差があるものの, 成 形条件や比較位置による界面位置の変動はよい一致を 示している. 第 4 層と第 5 層の境界面位置については 標準条件で定量的に大きな差があるが，観察位置によ る位置の変化の傾向は一致している．これはシミュレ ーションに拈いて結晶化挙動が充分に表しきれないこ とや樹脂物性データが成形時の条件下で測定されてい ないために生じているための誤差によるものと考兄ら れ，特に，ゲートシールのよらな物性值や結晶化の依 存性の大きな現象については現在の射出成形シミュレ ーションに执いて定量予測が困難なことを示している.

以上から，第 3 層と第 4 層の境界は射出から保圧へ の切り替光時の固化層成長速度の差異により生じてお り, 第 4 層と第 5 層の境界はゲートシール時の固化層 成長速度の差異が影響していると考兄られる.

他の層の生成原因は解析結果からは推測できないが, 第 1，2 層は成形条件や部位による差異がないことか ら，樹脂が金型に接触した瞬間に固化するスキン層で あり，第 6 層は，無せん断領域でから最も冷却速度が 低いため, 高結晶化度の領域と推測できる.

\section{4. 結 論}

本稿では射出成形シミュレーション結果から得られ たキャビティ内の樹脂の固化層成長や応力場などと射 出成形品の断面偏光写真から得られた層構造の関連性 について, 種々の成形条件と部位において調べた. そ の結果, 以下の結論が得られた。

(1) 射出成形プロセスに执いて, 成形条件にかかわ らず固液境界面でのせん断応力が大きく変化する 表面からの深さと，固化層成長速度が不連続にな る位置が一致することが明らかになった。また， その位置は射出から保圧への切り替わり, および ダートシールのタイミングと関連している.

(2) 断面偏光写真から得られた層の境界面位置とシ ミュレーション結果から得られた固化層成長速度 の急変部の位置はほぼ一致している。

(3) 以上から，層構造の発生原因として固化層の成 長速度と固液境界面のせん断応力の变化が支配的 である。

今後は各々の層に打ける物性值分布之樹脂挙動の関 係を明確にし，最終的には流動解析結果を用いて物性 值分布を予測し，物性值分布が要因となって発生する 残留応力を考慮したそり変形解析手法の開発を行う.

\section{参考文 献}

1）藤山光美, 木村修吉: 高分子論文集, 32 (10), 581 (1975)

2）藤山光美，木村修吉：高分子論文集， 32 (10), 591 (1975)

3) Fujiyama, M. and Wakino, T. : J. Appl. Polym. Sci., 34 (1), 1 (1998)

4) 宮本 玲, 松井裕次, 宇田 徹, 橋本壽正 : 成形 成工，5（4)，262(1993)

5) Trotignon, J. P. and Verdu, J. : J. Appl. Polym. Sci., 34 (1), 1 (1987)

6) Kantz, M. R. : Intern. J. Polym. Mater., 3, 245 (1974)

7）松本喜代一, 三浦一郎, 村田建世：高分子論文集, 36 (6), 401 (1979)

8）石島 守, 山部昌, 下田洋彰, 新保實, 宮野 靖: 成形加工, 5 (11)，792 (1993) 